\title{
Pencegahan Kekerasan Dalam Rumah Tangga Melalui Perjanjian Perkawinan (Tinjauan Hukum Islam)
}

\author{
Rini \\ Karyawan Swasta di Palangka Raya \\ Rini554@gmail.com
}

\begin{abstract}
The aggrement of marriage can be used as a legal instrument prevention of household violence. Payload contents in a marital agreement in the form of protection against violence carried out both from the husband to the wife to the husband or wife. The study belong to library research. More specifically, the type of research was also called normative legal research within the framework of prescriptive Islamic law by using approaches law (statue approach), the conceptual approach (conceptual approach), and analytical approach (analytical approach), using the method of data collection descriptive and deductive. The results of the study concluded that: Covenant marriage of a preventive nature has legitimate power, because it made notaril by the competent authority (notary) and legal certainty for married couples to refrain from domestic violence and to husbands and wives can exercise their rights and obligations in household well. The marriage covenant can be used also as a condition of lawful that must exist in marriage to provide legal protection in concrete terms with a form of protection and certainty in guaranteeing the rights and duties of husband and wife in order to realize the objectives of households that sakinah, mawaddah, dan rahmah as an objective.
\end{abstract}

Keywoards: prevention, household violence, Islamic law.

\section{A. Pendahuluan}

Kekerasan dalam rumah tangga merupakan tindakan pelanggaran hak asasi manusia dalam lingkup rumah tangga. Korban kekerasan dalam rumah tangga adalah istri dan anak. Kebanyakan korban rumah tangga tidak berani melakukan perlawanan atau advokasi secara hukum. Secara yuridis dalam Undang-Undang Nomor 23 Tahun 2004 Tentang Penghapusan Kekerasan Dalam Rumah Tangga (selanjutnya disingkat UU No. 23 Tahun 2004) memberikan perlindungan bagi korban yang termuat dalam Pasal 5 yang menyebutkan bahwa setiap orang dilarang melakukan kekerasan dalam rumah tangga terhadap orang 
dalam lingkup rumah tangganya, dengan cara: kekerasan fisik; kekerasan psikis; kekerasan seksual; atau penelantaran rumah tangga. ${ }^{1}$

Menurut UU No. 23 Tahun 2004 memberikan perlindungan, penghormatan, dan pemulihan kekerasan dalam rumah tangga dengan muatan norma hukum yang bersifat preventif (pencegahan), dan juga bersifat refresif (penanggulangan) yang melarang terjadinya kekerasan dalam rumah tangga dan sanksi pidana serta sanksi denda terhadap pelaku kekerasan dalam rumah tangga. Namun pada kenyataannya secara sosiologis tidak semua masyarakat memahami dan mengerti akan norma hukum tersebut. Akibatnya kekerasan dalam rumah tangga masih tetap terjadi dalam tataran sosiologis. Kekerasan dalam rumah tangga terjadi akibat kurangnya pemahaman mengenai hak dan kewajiban suami dan istri, sehingga terjadi ketidaksetaraan kedudukan suami dan istri.

Perlunya suatu payung hukum untuk memberikan perlindungan dan menjamin kepastian hak dan kewajiban suami dan istri dalam membina kelangsungan rumah tangga untuk mencapai tujuan perkawinan sebagaimana asas atau prinsip perkawinan yang terdapat dalam Undang-Undang Nomor 1 Tahun 1974 Tentang Perkawinan, menurut Sudarsono mengatakan bahwa:

Tujuan perkawinan adalah membentuk keluarga yang bahagia dan kekal. Untuk itu suami istri saling membantu dan melengkapi, agar masingmasing dapat mengembangkan kepribadiannya membantu dan mencapai kesejahteraan spritual dan materil. ${ }^{2}$

Untuk mewujudkan tujuan perkawinan diperlukan kesepakatan dan kesepahaman yang dibuat secara konkret melalui perjanjian perkawinan ${ }^{3}$ sebagai pencegah terjadinya kekerasan dalam rumah tangga. Konstruksi hukum dalam

\footnotetext{
${ }^{1}$ Pasal 5 Undang-Undang Nomor 23 Tahun 2004 Tentang Penghapusan Kekerasan Dalam Rumah Tangga. Lihat juga Undang-Undang RI Nomor 23 Tahun 2004 Tentang Penghapusan Kekerasan Dalam Rumah Tangga, Bandung: Citra Umbara, 2007, h. 4.

${ }^{2}$ Sudarsono, Hukum Perkawinan Nasional, Jakarta: Rineka Cipta, 2010, h. 7.

${ }^{3} \mathrm{http} / / / w w w . h u k u m o n l i n e$, diakses pada hari Sabtu, Tanggal 16 Mei 2015, pukul 12.23 wib. Mendefinisikan perjanjian perkawinan adalah perjanjian diantara calon suami istri yang tujuannya berakibat pada harta perkawinan mereka kelak. Pada Kitab Undang-undang Hukum Perdata (KUHPer), salah satu akibat perkawinan adalah persatuan harta secara menyeluruh (campuran bulat). Sedangkan pada UU No. 1 Tahun 1974 tentang Perkawinan, terjadi harta bersama setelah menikah.
} 
UU No. 23 Tahun 2004 memuat norma pencegahan dan penanggulangan kekerasan dalam rumah tangga, sedangkan dalam Kompilasi Hukum Islam hanya memuat norma tentang hak dan kewajiban suami dan istri secara abstrak, maka diperlukan hukum konkret yang memuat hak dan kewajiban suami dan istri secara khusus dalam bentuk perjanjian perkawinan.

Perlunya hukum konkret yang dilakukan melalui abstraksi atau rekonstruksi hukum untuk memberikan perlindungan dan menjamin kepastian hak dan kewajiban suami dan istri dalam membina rumah tangga untuk mencapai tujuan perkawinan yang sesuai dengan peraturan perundang-undangan yang berlaku dan sesuai dengan hukum Islam pada tataran filosofis. Sebab, dalam membina rumah tangga diliputi norma-norma yang mempengaruhi tingkah laku pasangan suami istri, seperti norma agama, norma kesusilaan, norma kesopanan.

Senyatanya pada proses pra perkawinan biasanya calon suami dan calon istri berjanji secara lisan kepada calon pasangannya dengan itikad baik akan memperlakukan pasangan dan melakukan kewajiban dan menuntut haknya sesuai dengan porsinya masing-masing sebagai suami dan istri. Namun, setelah terjadi perkawinan masalah muncul, seperti ketidaksepahaman dalam menjalani kehidupan berumah tangga apalagi sampai terjadi kekerasan dalam rumah tangga. Fenomena perjanjian perkawinan yang dilakukan oleh Raffi Ahmad dan Nagita Slavina (artis/bintang) menunjukkan pentingnya suatu payung hukum bagi pasangan tersebut dalam menjamin hak dan kewajiban mereka sebagai suami istri. Pemahaman masyarakat tentang perjanjian perkawinan belum sepenuhnya diketahui dan dimengerti manfaatnya, sehingga dianggap tabu bagi masyarakat. Sebab, hanya kalangan masyarakat menengah atas yang mengerti dan paham akan pentingnya manfaat perjanjian perkawinan. Maka berdasarkan hal tersebut untuk mencegah terjadinya kekerasan dalam rumah tangga perlu dibuat perjanjian tertulis dalam suatu perkawinan sebagai hukum kongkret yang sesuai dengan hukum positif dan hukum Islam agar melindungi hak dan 
kewajiban suami dan istri ${ }^{4}$ dalam bentuk yuridis formal secara konkret melalui perjanjian perkawinan. ${ }^{5}$

Sebagian besar masyarakat belum sepenuhnya mengetahui mengenai manfaat dari perjanjian perkawinan serta kurangnya minat dari masyarakat untuk melakukan perjanjian tersebut. Bahkan sebagian masyarakat menganggap bahwa perjanjian perkawinan yang dilakukan sebelum melangsungkan perkawinan hanya akan merusak nilai-nilai dari tujuan perkawinan nantinya yang menginginkan rumah tangga sakinah, mawaddah dan rahmah. Lebih lanjut berdasarkan data yang penulis dapat, dari 100 (seratus) perkawinan yang telah dilangsungkan di Kantor Urusan Agama Kota Palangka Raya, hanya sekitar 1 (satu) dari pasangan mempelai yang melakukan perjanjian perkawinan. Sehingga dari sekian banyaknya perkawinan yang telah dilangsungkan, perjanjian perkawinan dianggap sebagian masyarakat masih belum terlalu yakin dengan melakukan perjanjian perkawinan dapat melindungi perkawinan dari perceraian.

Melalui pemikiran di atas, diperlukan kajian hukum yang secara khusus dalam tataran teoritis mengenai pencegahan kekerasan dalam rumah tangga melalui perjanjian perkawinan sebagai alat atau payung hukum untuk memberikan perlindungan dan kepastian dalam menjamin hak dan kewajiban suami istri dalam rangka mewujudkan tujuan rumah tangga yaitu sakinah, mawaddah, dan rahmah sebagai tujuan syariat hukum Islam (maq\}as)id sya@ri'ah) dalam kedudukan hak dan kewajiban suami dan istri yaitu memelihara agama (hifz\}uldi@n), memelihara akal (hifz\}ul aqli), memelihara jiwa (hifz\}ul nafs), memelihara keturunan (hifz\}ul nash), memelihara harta

${ }^{4}$ Dalam konteks kekerasan psikis, hak istri untuk meminta tidak dipoligami (dapat menimbulkan kekerasan psikis). Hukum Islam memberikan hak kepada perempuan atau walinya untuk mensyaratkan (pernikahannya) bahwa ia tidak akan dipoligami. Istri tersebut berhak membatalkan pernikahannya apabila dikemudian hari suami melanggar syarat yang diucapkan pada waktu akad nikah bahwa suami tidak akan menikah dengan perempuan lain (poligami). Ini adalah pendapat Imam Ahmad yang juga ditegaskan oleh Ibnu Taimiyah dan Ibnu Qayyim. Lihat Sayyid Sabiq, Fiqih Sunnah Jilid 3, Jakarta: Tinta Abadi Gemilang, 2013, h. 354.

${ }^{5}$ Mardani, Hukum Islam (Pengantar Hukum Islam di Indonesia), Yogyakarta: Pustaka Pelajar, 2010, h. 2-3. 
(hifz\}ul mal), dan memelihara kehormatan (hifz\}ul irdh). Sebagaimana kaidah fikih دَفْعُ المَفَاسِدِ مُقَََّمُ عَلَى جَلْبِ المَصَالِِحِ (menolak mafsadah/kemudaratan didahulukan kepada meraih maslahat). ${ }^{6}$ Hal ini bertujuan untuk memberikan penghormatan, perlindungan, dan kepastian terhadap hak dan kewajiban suami dan istri, serta perlindungan terhadap hak anak ${ }^{7}$ melalui hukum konkret dalam membina rumah tangga dalam rangka mewujudkan tujuan perkawinan yang sakinah, mawaddah, dan rahmah.

Berdasarkan uraian di atas, penulis tertarik untuk melakukan penelitian mengenai perjanjian perkawinan sebagai pencegah kekerasan dalam rumah tangga dalam konstruksi hukum Islam. Maka perlu dibuat hukum konkret yang dibuat dalam perjanjian perkawinan dengan memperhatikan Pasal 1320 Kitab Undang-Undang Hukum Perdata (selanjutnya disingkat KUHPerdata) ${ }^{8}$ berdasarkan kesepakatan para pihak (suami dan istri) dalam memposisikan kedudukan masing-masing dengan segala hak dan kewajiban yang melekat sehingga menjadi hukum konkret (yuridis) bagi para pihak maka berlaku Pasal 1338 KUH Perdata (berlaku asas pacta sunt servanda) ${ }^{9}$ sesuai dengan peraturan perundang-undangan yang berlaku dan sesuai dengan hukum Islam untuk

${ }^{6}$ A. Djazuli, Kaidah-kaidah Fikih: Kaidah-kaidah Hukum Islam dalam Menyelesaikan Masalah-masalah yang Praktis, Jakarta: Kencana, 2007, h. 29.

${ }^{7}$ Hak anak adalah segala sesuatu yang harus didapatkan oleh anak, apabila tidak diperoleh maka anak berhak untuk menuntut. Hak anak tersebut mencakup non diskriminasi terhadap anak, kepentingan terbaik bagi anak, kelangsungan hidup, seperti yang dijelaskan pada Bab 1 Pasal 1 Nomor 12 dan Bab 11 Pasal 2 Undang-undang Nomor 23 Tahun 2002 Tentang Perlindungan Anak.

${ }^{8}$ Pasal 1320 KUHPerdata menyebutkan bahwa: Untuk sahnya suatu perjanjian diperlukan empat syarat: 1) sepakat mereka yang mengikatkan diri; 2) kecakapan untuk membuat suatu perikatan; 3) suatu hal tertentu; dan 4) suatu sebab yang halal. Adapun menurut R. Subekti menyebutkan bahwa suatu perjanjian dianggap sah apabila memenuhi syarat objektif dan syarat subjektif. Pemenuhan atas syarat objektif yaitu suatu suatu hal tertentu dan sebab yang halal, sedangkan syarat subjektif yaitu sepakat dan cakap. Hal ini berakibat pada perjanjian yang telah dibuat menjadi sah. Perjanjian mengikat para pihak mengenai hak dan kewajibannya, sehingga pemenuhan syarat sahnya perjanjian mutlak harus dipenuhi. Hal ini kelak apabila dikemudian hari terjadi suatu permasalahan atau sengketa maka penyelesaian dapat didasarkan pada perjanjian yang telah disepakati. Lihat R. Subekti, PokokPokok Hukum Perdata, Jakarta, Intermasa, 2001, h. 16.

${ }^{9}$ Pasal 1338 KUHPerdata menyebutkan bahwa: Semua perjanjian yang dibuat secara sah berlaku sebagai Undang-undang bagi mereka yang membuatnya; suatu perjanjian tidak dapat ditarik kembali selain dengan sepakat kedua belah pihak, atau karena alasan-alasan yang oleh Undang-undang dinyatakan cukup untuk itu; dan suatu perjanjian harus dilaksanakan dengan itikad baik. 
keberlangsungan rumah tangga dan dapat membudaya dalam tataran kehidupan masyarakat secara sosiologis. Maka berdasarkan permasalahan telah diuraikan, penulis tertarik untuk mengkaji permasalahan tersebut ke dalam bahasan skripsi dengan judul: "Pencegahan Kekerasan Dalam Rumah Tangga Melalui Perjanjian Perkawinan (Tinjauan Hukum Islam).”

\section{B. Kajian Pustaka}

Kekerasan secara terminologi menurut Moerty Hadiati dapat diartikan sebagai perihal yang bersifat keras atau perbuatan seseorang atau kelompok orang yang menyebabkan cidera atau matinya seseorang. ${ }^{10}$ Pada dasarnya bentuk-bentuk kekerasan ini dapat ditemui dan terkait pada bentuk perbuatan pidana tertentu, seperti pembunuhan, penganiayaan, pemerkosaan dan pencurian. Dalam Kitab Undang-Undang Hukum Pidana seringkali kekerasan dikaitkan dengan ancaman dan dapat disimpulkan bahwa kekerasan dapat berbentuk fisik dan nonfisik (ancaman kekerasan). ${ }^{11}$

Pasal 2 Deklarasi PBB tentang Penghapusan Kekerasan terhadap Perempuan dijelaskan bahwa:

Kekerasan terhadap perempuan adalah setiap perbuatan berdasarkan perbedaan kelamin yang berakibat atau mungkin berakibat kesengsaraan, dan penderitaan perempuan secara fisik, seksual atau psikologis, termasuk ancaman tindakan tertentu, pemaksaan atau perampasan kemerdekaan secara sewenang-wenang, baik yang terjadi di depan umum dalam kehidupan pribadi.

Adapun kekerasan terhadap anak adalah:

Setiap perubahan yang ditujukan pada anak yang berakibat kesengsaraan dan penderitaan fisik maupun psikis, baik yang terjadi di depan umum atau dalam kehidupan pribadi.

Tindak kekerasan tidak hanya berupa tindakan fisik, melainkan juga perbuatan nonfisik (psikis). Tindakan fisik langsung bisa dirasakan akibatnya oleh korban, serta dapat dilihat oleh siapa saja, sedangkan tindakan nonfisik

\footnotetext{
${ }^{10}$ Moerti Hadiati Soeroso, Kekerasan Dalam Rumah Tangga Dalam Perspektif YuridisViktimologis, Jakarta: Sinar Grafika, 2012, h. 58.

${ }^{11}$ Ibid.
} 
(psikis) yang bisa merasakan langsung hanyalah korban, karena tindakan tersebut langsung menyinggung hati nurani atau perasaan seseorang. ${ }^{12}$

Secara umum rumah tangga merupakan organisasi terkecil dalam masyarakat yang terbentuk karena adanya ikatan perkawinan. Pengertian rumah tangga tidak tercantum dalam ketentuan khusus, tetapi pengertian keluarga yang tercantum dalam Pasal 1 angka 30 Undang-Undang Nomor 8 Tahun 1981 tentang Kitab Undang-Undang Hukum Acara Pidana: "Keluarga adalah mereka yang mempunyai hubungan darah sampai derajat tertentu atau hubungan perkawinan."

Terjadinya kekerasan dalam sebuah rumah tangga sebenarnya bukan merupakan hal yang baru. Namun selama ini selalu dirahasiakan oleh keluarga maupun korban sendiri. Budaya masyarakat ikut berperan dalam hal ini, karena tindak kekerasan apapun bentuknya yang terjadi dalam sebuah rumah tangga atau keluarga adalah merupakan masalah keluarga. ${ }^{13}$

Mewujudkan keutuhan dan kerukunan dalam rumah tangga adalah dambaan setiap orang. Pada setiap orang dalam lingkup rumah tangga tersebut untuk memahami perannya, terutama kadar kualitas perilaku dan pengendalian diri setiap orang dalam lingkup rumah tangga. Keutuhan dan kerukunan rumah tangga dapat terganggu jika kualitas dan pengendalian diri tidak dapat dikontrol yang pada akhirnya dapat terjadi kekerasan dalam rumah tangga sehingga timbul rasa tidak aman, ketidakadilan, maupun ketidaknyamanan terhadap orang yang berada dalam lingkup rumah tangga tersebut. Pengaturan konstruksi hukum tentang kekerasan dalam rumah tangga dalam sistem peraturan perundangundangan di Indonesia adalah sebagai berikut:

Menurut Undang-Undang Nomor 23 Tahun 2004 Tentang Penghapusan Kekerasan Dalam Rumah Tangga Pasal 1 poin 1, yang dimaksud dengan kekerasan dalam rumah tangga (KDRT) adalah setiap perbuatan kepada seseorang terutama perempuan yang berakibat timbulnya kesengsaraan atau penderitaan secara fisik, seksual, psikologis dan atau penelantaran rumah tangga

\footnotetext{
${ }^{12}$ Ibid., h. 60.

13 lbid., h. 61.
} 
termasuk ancaman untuk melakukan perbuatan, pemaksaan, atau perampasan kemerdekaan secara melawan hukum dalam lingkup rumah tangga. ${ }^{14}$

Pada Pasal 1 Undang-Undang Nomor 1 Tahun 1974 Tentang Perkawinan berbunyi:

Perkawinan adalah ikatan lahir batin antara pria dengan seorang wanita sebagai suami istri dengan tujuan membentuk keluarga (rumah tangga) yang berbahagia dan kekal berdasarkan Ketuhanan Yang Maha Esa.

Tujuan perkawinan adalah membentuk keluarga bahagia dan kekal. Untuk itu suami istri perlu saling membantu dan melengkapi agar masing-masing dapat mengembangkan kepribadiannya membantu dan mencapai kesejahteraan spiritual dan material. Kemudian adapun hak dan kedudukan istri adalah seimbang dengan hak dan kedudukan suami, baik dalam kehidupan rumah tangga maupun dalam pergaulan masyarakat. Dengan demikian segala sesuatu dalam keluarga dapat dirundingkan dan diputuskan bersama oleh suami istri. ${ }^{15}$

Uraian di atas, menggambarkan bahwa sebuah rumah tangga mencerminkan suasana tentram, damai, dan penuh kebahagiaan. Namun dalam kenyataannya terdapat kondisi yang sebaliknya. Karena kebahagiaan dan keharmonisan rumah tangga, terkoyak oleh adanya tindak kekerasan dalam lingkup rumah tangga oleh pelaku tindak kekerasan, baik pelaku maupun korban dalam hubungan keluarga seperti suami, istri, dan anak, maupun hubungan kerja seperti pembantu rumah tangga. ${ }^{16}$

\section{Metode Penelitian}

Penelitian ini disebut juga sebagai penelitian kepustakaan (library research), yaitu penelitian yang dilakukan melalui bahan-bahan pustaka atau literatur kepustakaan sebagai sumber tertulis. Lebih spesifik, jenis penelitian ini

\footnotetext{
${ }^{14}$ Wahyu Kuncoro, Tips Hukum Praktis: Solusi Cerdas Menghadapi Kasus Keluarga, Jakarta: Raih Asa Sukses, 2010, h. 218.

${ }^{15}$ Moerti Hadiati Soeroso, Kekerasan Dalam Rumah Tangga ..., h. 161.

${ }^{16}$ Ibid.
} 
juga disebut penelitian hukum normatif ${ }^{17}$ dalam kerangka preskriptif hukum Islam. Data dikumpulkan dengan menggunakan teknik penelaahan terhadap referensi-referensi yang relevan dan berhubungan dengan permasalahan yang akan diteliti, khususnya pencegahan kekerasan dalam rumah tangga melalui perjanjian perkawinan dalam kontruksi hukum Islam. ${ }^{18}$

\section{Pembahasan}

Kekerasan dalam rumah tangga seperti yang telah penulis paparkan pada bab sebelumnya ialah setiap perbuatan terhadap seseorang terutama perempuan yang berakibat timbulnya kesengsaraan atas penderitaan secara fisik, seksual, psikologis, dan atau penelantaran rumah tangga termasuk ancaman untuk melakukan perbuatan, pemaksaan, atau perampasan kemerdekaan secara melawan hukum dalam lingkup rumah tangga. Kekerasan merupakan suatu tindakan yang membuat korbannya menjadi tidak berdaya, sengsara dan bahkan menimbulkan tekanan bagi psikisnya. ${ }^{19}$

Adapun unsur-unsur yang terdapat pada kekerasan dalam rumah tangga terhadap seseorang meliputi: Kekerasan fisik; Kekerasan psikis; Kekerasan seksual; dan Penelantaran rumah tangga. ${ }^{20}$ Semakin banyaknya kasus kekerasan dalam rumah tangga yang terjadi pada masa sekarang serta diikuti dengan meningkatnya angka perceraian menjadi kekhawatiran bagi pasangan lain yang telah menikah. Seperti yang terdapat pada data Lembar Fakta Catatan Tahunan (CATAHU) Komisi Nasional Perempuan menunjukkan bahwa pada tahun 2013 ada 279.760 kasus kekerasan terhadap perempuan yang dilaporkan dan ditangani selama tahun 2013, yang terdiri dari 263.285 kasus bersumber pada data

\footnotetext{
${ }^{17}$ Sudikno Mertokusumo, Penemuan Hukum, Yogyakarta: Universitas Atma Jaya, 2010, h. 37.

${ }^{18}$ Penelitian tipe ini lazim disebut sebagai "studi dogmatik" atau yang dikenal dengan doctrinal research. Lihat Bambang Sunggono, Metodologi Penelitian Hukum, Jakarta: Rajawali Pers, 2012, h. 86. Lihat juga Soerjono Soekanto dan Sri Mamudji, Penelitian Normatif, Jakarta: Rajawali Pers, 2010, h. 113.

${ }^{19}$ Lihat Pasal 1 Undang-Undang Nomor 23 Tahun 2004 Tentang Penghapusan Kekerasan Dalam Rumah Tangga.

${ }^{20}$ Lihat Pasal 5 Undang-Undang Nomor 23 Tahun 2004 Tentang Penghapusan Kekerasan Dalam Rumah Tangga.
} 
kasus/perkara yang ditangani oleh 359 Pengadilan Agama (data BADILAG), serta 16.403 kasus yang ditangani oleh 195 lembaga mitra pengada layanan, tersebar di 31 Provinsi. Sedangkan pada tahun 2014 meningkat menjadi 293.220 sebagian besar dari data tersebut diperoleh dari data kasus/perkara yang ditangani oleh 359 Pengadilan Agama di tingkat kabupaten/kota yang tersebar di 30 Provinsi di Indonesia, yaitu mencapai 280.710 kasus atau berkisar $96 \%$. Sisanya sejumlah 12.510 kasus atau berkisar 4\% bersumber dari 191 lembaga-lembaga mitra pengadalayanan yang merespon dengan mengembalikan formulir pendataan yang dikirimkan oleh Komnas Perempuan. Kemudian, pada tahun 2015 jumlah kasus kekerasan terhadap perempuan mencapai 321.752 bersumber pada data kasus/perkara yang ditangani oleh Pengadilan Agama atau Badan Peradilan Agama (PA-BADILAG) sejumlah 305.535 kasus, dan dari lembaga layanan mitra Komnas Perempuan sejumlah 16.217 kasus. $^{21}$

Tindak kekerasan dalam rumah tangga yang terjadi disebabkan laki-laki dan perempuan tidak berada dalam posisi yang setara dalam suatu rumah tangga. Padahal hak dan kewajiban yang dimiliki oleh laki-laki maupun perempuan adalah sama tanpa membedakan gender/jenis kelamin. Seperti yang terdapat dalam Pasal 79 ayat (1) Kompilasi Hukum Islam mengatakan bahwa suami adalah kepala keluarga dan istri adalah ibu rumah tangga. Lebih lanjut pada ayat (2) bahwa hak dan kedudukan istri adalah seimbang dengan hak dan kedudukan suami dalam rumah tangga dan pergaulan hidup bersama dalam masyarakat. ${ }^{22}$ Kemudian kekerasan yang terjadi di dalam rumah tangga dianggap bukan sebagai permasalahan sosial, akan tetapi persoalan pribadi terhadap relasi antara suami dan istri. Karena ruang lingkup yang hanya mencakup di dalam rumah tangga.

\footnotetext{
${ }^{21} \mathrm{http} / / /$ www.komnasperempuan.or.id, diakses pada Hari Minggu, Tanggal 23 April 2016, pukul 13.34 wib.

${ }^{22}$ Lihat Pasal 76 Kompilasi Hukum Islam (Instruksi Presiden Tahun 1991). Lihat juga Ahmad Tholabi Kharlie, Hukum Keluarga Indonesia, h. 251.
} 
Namun, walaupun Undang-Undang Nomor 23 Tahun 2004 Tentang Penghapusan Kekerasan Dalam Rumah Tangga (selanjutnya disingkat UU No. 23 Tahun 2004) dibuat dimaksudkan untuk memberikan efek jera bagi pelaku tindak kekerasan. Serta ancaman sanksi hukuman yang telah penulis paparkan pada bab sebelumnya, tidak mencantumkan batasan minimal dan maksimal akan tetapi hanya berupa ancaman hukuman alternatif berupa kurungan atau denda. Bila dibandingkan dengan dampak yang diterima bagi korban maka sanksi yang diberikan kepada pelaku masih terlalu ringan, bahkan lebih menguntungkan bila menggunakan ketentuan hukum sebagaimana yang diatur dalam Kitab UndangUndang Hukum Pidana. Apalagi jika korban mengalami cacat fisik, psikis, atau bahkan hilangnya nyawa seseorang. Undang-Undang seharusnya memfokuskan pada proses penanganan hukum pidana dan penghukuman dari korban, serta perlunya upaya strategis dari korban guna mendukung dan memberikan perlindungan dalam rangka mengungkapkan kasus kekerasan dalam rumah tangga.

Hal yang menjadi latar belakang diundangkan UU No. 23 Tahun 2004 adalah adanya kesadaran atas diskriminasi dan perlakuan yang tidak adil terhadap perempuan maupun laki-laki baik dalam ruang publik ataupun dalam rumah tangga. UU No. 23 Tahun 2004 menjadi ketentuan hukum yang mengatur tentang tindak kekerasan dalam rumah tangga, prosedur pada penanganan perkara, dan juga perlindungan terhadap korban dan sanksi bagi pelaku. Disahkannya UU No. 23 Tahun 2004 bukan berarti telah menyelesaikan tanggung jawab pemerintah untuk melindungi. Bahkan dengan telah disahkannya UU No. 23 Tahun 2004 merupakan titik awal bagi pemerintah serta aparat hukum agar dapat mengawasi dan menindaklanjuti mengenai kasus kekerasan yang terjadi dalam rumah tangga.

Perlindungan hukum terhadap pencegahan kekerasan dalam rumah tangga, secara yuridis dapat dikaji dari rumusan yang tercantum dalam perundang-undangan berikut. Pada Pasal 1 ayat (5) UU No. 23 Tahun 2004 telah 
disajikan mengenai rumusan tentang perlindungan. Perlindungan yang dimaksud adalah:

Segala upaya yang ditujukan untuk memberikan rasa aman kepada korban yang dilakukan oleh pihak keluarga, advokat, lembaga sosial, kepolisian, kejaksaan, pengadilan, atau pihak lainnya baik sementara maupun berdasarkan penetapan keadilan. ${ }^{23}$

Tujuan perlindungan adalah memberikan rasa aman bagi korban dari tindak kekerasan. Rasa aman adalah bebas dari bahaya, bebas dari gangguan, tentram, tidak merasa takut atau khawatir terhadap suatu hal seperti yang tercantum pada UU No. 23 Tahun 2004 Pasal 1 ayat (6). Bentuk perlindungan hukum secara teoretis dibagi menjadi dua bentuk yaitu: a) perlindungan yang bersifat preventif; dan b) perlindungan yang bersifat refresif. Perlindungan hukum yang bersifat preventif merupakan perlindungan hukum yang sifatnya dilakukan untuk pencegahan. ${ }^{24}$ Maka dengan dibuatnya UU No. 23 tahun 2004 bertujuan untuk mencegah agar tidak terjadinya tindak kekerasan dalam rumah tangga yang dilakukan oleh pelaku. Sehingga, dengan adanya perlindungan hukum bersifat preventif akan mencegah dari tindakan yang melanggar hak seseorang.

Namun sebagian besar dari korban kekerasan yang terjadi dalam rumah tangga adalah dari pihak perempuan (istri) dan pelakunya adalah dari suami. Walaupun ada juga korban dari kekerasan yang terjadi justru malah sebaliknya dari pihak suami dan pelakunya adalah istri, ataupun orang-orang yang tersubordinasi di dalam rumah tangga. Korban dari tindak kekerasan yang terjadi dalam rumah tangga adalah orang yang mempunyai hubungan darah, dengan sebab dari perkawinan, persusuan, pengasuhan, perwalian dengan suami, dan

\footnotetext{
${ }^{23}$ Lihat Pasal 1 ayat (5) Undang-Undang Nomor 23 Tahun 2004 Tentang Penghapusan Kekerasan Dalam Rumah Tangga.

${ }^{24}$ Lihat Salim HS, dan Erlies Septiana Nurbani, Penerapan Teori Hukum pada Penelitian Tesis dan Disertasi..., h. 264.
} 
anak bahkan pembantu rumah tangga yang tinggal di dalam rumah tangga tidak lepas dari tindak kekerasan.

Akan tetapi, tidak semua tindakan kekerasan dalam rumah tangga dapat ditangani secara tuntas karena korban sering menutup-nutupi dengan alasan ikatan struktur budaya, agama, dan belum dipahaminya sistem hukum yang berlaku. Korban dari tindak kekerasan lebih memilih untuk menerima semua perlakuan yang diberikan dengan alasan untuk menjaga dan mempertahankan rumah tangga. Padahal, disamping itu korban memerlukan perlindungan yang cukup kuat oleh negara dan masyarakat bertujuan memberikan rasa aman terhadap korban.

Kekerasan dalam rumah tangga yang terjadi pada sebagian keluarga mempunyai banyak dampak yang cukup memprihatinkan. Ruang lingkup dalam rumah tangga yang di dalamnya terdapat suami sebagai pemimpin dan kepala rumah tangga serta di samping itu istri yang ikut berperan dalam hal membantu suami dalam menjalankan rumah tangga agar dapat membangkitkan ketenangan, ketentraman dan kenyamanan bagi yang berada dalam rumah tangga. Akan tetapi, ketika adanya tindakan kekerasan yang terjadi dalam rumah tangga mengakibatkan pada hubungan suami istri maupun kepada anak-anak menjadi kurang harmonis.

Padahal, seharusnya dengan adanya UU No. 23 tahun 2004 dapat dijadikan sebagai bentuk atas perlindungan hukum terhadap korban. Akan tetapi, UU No. 23 Tahun 2004 masih dinilai belum cukup dan dinilai masih kurang untuk menjamin keselamatan bagi korban tindak kekerasan. Meskipun UU No. 23 tahun 2004 telah disahkan tetapi pada kenyataannya masih banyak terjadinya pelanggaran terhadap kekerasan dalam rumah tangga. Sebagian besar korban dari tindak kekerasan adalah perempuan, dan juga menyangkut kepada anak-anak. Maka dari itu diperlukan suatu instrumen hukum sebagai pencegahan terhadap kekerasan dalam rumah tangga melalui perjanjian perkawinan yang dibuat sebelum diadakannya perkawinan. Dengan melakukan perjanjian perkawinan 
dapat mencegah apabila kelak suatu saat setelah terjadinya perkawinan dan kemudian terjadi suatu pelanggaran hak asasi manusia serta tindak kekerasan maka melalui perjanjian perkawinan dapat dijadikan sebagai alat yang mengingatkan (reminder) bagi yang membuat perjanjian perkawinan tersebut agar tidak melakukan tindak kekerasan dan melihat kepada sanksi yang didapat apabila dari salah satu melanggar dari isi perjanjian.

Perjanjian perkawinan berperan sebagai suatu bentuk atas perlindungan kepada pasangan suami istri dalam berkehidupan rumah tangga. Suami maupun istri sebelum melakukan perkawinan terlebih dahulu mereka membuat kesepakatan untuk melakukan perjanjian perkawinan. Dengan membuat perjanjian perkawinan suami istri berkeinginan agar dalam perkawinan untuk melindungi hak-hak dari keduanya maka diperlukan suatu perjanjian yang dapat mengikat keduanya saat perkawinan telah dilangsungkan. Akan tetapi, permasalahan yang berada pada sebagian masyarakat yang masih belum mengetahui dan memahami perjanjian perkawinan menganggap perjanjian perkawinan tidak perlu dilakukan. Padahal, melihat dari banyaknya angka kasus perceraian yang diakibatkan karena kekerasan dalam rumah tangga diperlukan solusi untuk mencegah terjadinya kekerasan tersebut.

Maka berdasarkan analisis penulis di atas, melalui pendekatan perundangundangan dan pendekatan konseptual perjanjian perkawinan dapat dijadikan sebagai instrumen hukum pencegahan kekerasan dalam rumah tangga, sebab memiliki kekuatan mengikat secara yuridis normatif yang bersifat pencegahan (preventif). Hal ini menunjukkan kepastian hukum bagi pasangan suami istri agar tidak melakukan kekerasan dalam rumah tangga, sebab dalam perumusan dan pembuatan perjanjian perkawinan kedua belah pihak suami istri akan mengetahui hak dan kewajiban mereka masing-masing dalam rumah tangga.

Perjanjian taklik talak dan perjanjian diluar dari taklik talak, maka penulis ringkas melalui tabel 1 sebagai berikut: 
Tabel 1

\begin{tabular}{|c|c|c|}
\hline \multirow{3}{*}{$\begin{array}{l}\text { Rumusan Masalah } \\
\text { 1. Apakah } \\
\text { Perjanjian } \\
\text { Perkawinan } \\
\text { dapat dijadikan } \\
\text { sebagai } \\
\text { instrumen hukum } \\
\text { pencegah } \\
\text { kekerasan dalam } \\
\text { rumah tangga? }\end{array}$} & Pokok Bahasan & Kesimpulan Analisis \\
\hline & $\begin{array}{l}\text { Bentuk-Bentuk } \\
\text { perjanjian: } \\
\text { 1.Taklik Talak }\end{array}$ & $\begin{array}{l}\text { Taklik Talak tidak dapat } \\
\text { sepenuhnya dijadikan sebagai } \\
\text { instrumen PKDRT karena Taklik } \\
\text { talak adalah perjanjian yang } \\
\text { diucapkan hanya secara sepihak } \\
\text { bagi calon suami setelah akad } \\
\text { nikah atas persetujuan dari pihak } \\
\text { suami yang menyanggupi } \\
\text { mengenai isi taklik talak. } \\
\text { Substansi yang terdapat di dalam } \\
\text { taklik talak belum meliputi } \\
\text { secara keseluruhan mengenai } \\
\text { hal-hal yang terkandung pada } \\
\text { kekerasan dalam rumah tangga } \\
\text { yakni kekerasan secara fisik, } \\
\text { psikis, seksual dan penelantaran } \\
\text { rumah tangga. Perjanjian taklik } \\
\text { talak hanya akan berlaku sesudah } \\
\text { akad nikah, akan tetapi setelah } \\
\text { taklik talak dibacakan maka } \\
\text { taklik talak tidak dapat dicabut } \\
\text { kembali. }\end{array}$ \\
\hline & $\begin{array}{l}\text { 2. Perjanjian Selain } \\
\text { Taklik Talak }\end{array}$ & $\begin{array}{l}\text { Perjanjian } \\
\text { merupakan suatu janji yang } \\
\text { dibuat oleh calon suami istri } \\
\text { sebelum melangsungkan } \\
\text { perkawinan. Isi dari perjanjian } \\
\text { perkawinan dibuat oleh calon } \\
\text { suami istri dan ditentukan } \\
\text { dengan kebebasan kedua belah } \\
\text { pihak asalkan tidak melanggar } \\
\text { batas-batas hukum dan syariat } \\
\text { Islam. Perjanjian perkawinan } \\
\text { berlaku setelah akad nikah } \\
\text { dilangsungkan. Isi perjanjian } \\
\text { perkawinan yang telah dibuat } \\
\text { maka telah berlaku sebagai } \\
\text { undang-undang bagi kedua belah }\end{array}$ \\
\hline
\end{tabular}


pihak, dan selama perkawinan perjanjian tidak dapat dirubah bagi suami atau istri kecuali dengan kesepakatan bersama dan selama perubahan perjanjian tidak merugikan bagi pihak ketiga.

Allah SWT menciptakan laki-laki dan perempuan agar dapat berhubungan satu sama lain, saling mencintai, menghasilkan keturunan, dan hidup berdampingan secara damai dan sejahtera sesuai dengan perintah Allah SWT dan petunjuk Rasulullah SAW. ${ }^{25}$ Maka dari itu Islam sangat memperhatikan masalah dalam suatu keluarga. Sebab, Islam tidak mengabaikan peranan pribadi anggota keluarga namun juga memberikan hak bagi setiap anggota sesuai dengan kedudukannya, kemudian mewajibkannya untuk memegang tanggung jawab dengan penuh ketakwaan.

Untuk memelihara kedamaian dan ketertiban dalam kehidupan keluarga muslim, Allah SWT telah menerangkan dalam potongan Q.S. An-Nisa> [4]: 34 sebagai berikut:

Artinya: "Kaum laki-laki itu adalah pemimpin bagi kaum wanita..."

Kata "Qawwa>>>mu>>>n" dalam ayat tersebut adalah pemimpin dan penanggung jawab atas para wanita. Dan kaum lelaki diperintahkan sebagai pelindung dan pemelihara bagi kaum perempuan. ${ }^{26}$ Kaum laki-laki berperan untuk mengurusi kaum wanita dalam perintah dan larangan, nafkah serta arahan, sebagaimana seorang pemimpin mengurusi rakyatnya. Menekankan pada seseorang yang bertanggung jawab untuk menjamin dan melindungi kepentingan orang lain. Maka, kedudukan ini diberikan kepada kaum lelaki atas kaum perempuan, karena secara umum laki-laki memiliki kekuatan fisik lebih kuat dan

\footnotetext{
${ }^{25}$ Rahman I. Doi, Penjelasan Lengkap Hukum-Hukum Allah (Syariah), Jakarta: PT RajaGrafindo Persada, 2002, h. 150.

${ }^{26}$ M. Quraish Shihab, Tafsir Al-Mishbah: Pesan, Kesan, dan Keserasian Al-Qur'an, Jakarta: Lentera Hati, 2002, h.509.
} 
lebih besar untuk bekerja keras. Lebih dari itu, karena kaum lelaki adalah pemimpin bagi perempuan dan bertanggung jawab atas dirinya. Adanya seorang pemimpin yang akan memberikan pengarahan dan menata di antara anggota keluarga merupakan hal yang sangat penting dalam keluarga. ${ }^{27}$

Pencegahan kekerasan dalam rumah tangga menurut $M a q\} a s\}$ id Sya $>$ ri'ah dan pencegahan kekerasan dalam rumah tangga melalui perjanjian perkawinan menurut $A d z$-dzarî'ah, maka penulis ringkas melalui tabel 4.2 sebagai berikut:

Tabel 4.2

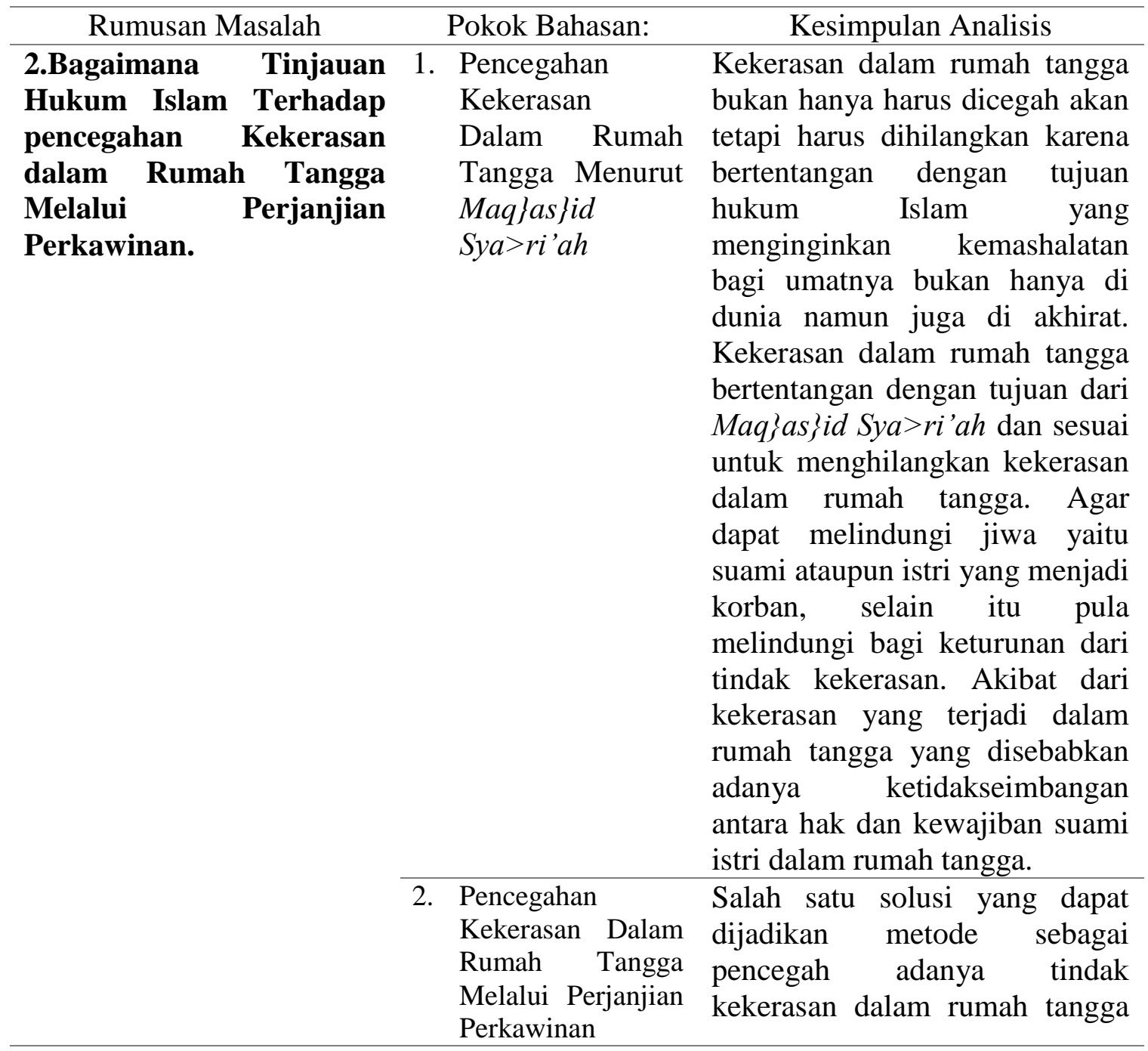

${ }^{27}$ Muhammad Ali Ash-Shabuni, Shafwatut Tafasir: Tafsir-Tafsir Pilihan (Jilid 1), Jakarta Timur: Pustaka Al-Kautsar, 2011, h. 636. 
Menurut

$A d z-$ dipandang melalui sadd adzdzarî̀ah dzarî'ah, yakni dengan menutup kemungkinan untuk terjadinya perceraian. Maka, diperlukan suatu jalan untuk menutup kemungkinan terhadap suami istri dalam melakukan perceraian dengan melalui perjanjian perkawinan. Perjanjian perkawinan dijadikan sebagai pengingat (reminder) bagi suami istri agar tidak melakukan kekerasan dalam rumah tangga dengan melihat kemudaratan yang didapat apabila kekerasan terjadi.

\section{E. Kesimpulan}

Berdasarkan hasil penelitian yang telah dilakukan oleh penulis, maka dapat disimpulkan adalah sebagai berikut: Perjanjian perkawinan sebagai bentuk konkretisasi dari taklik talak sebab, perjanjian perkawinan dapat dijadikan sebagai salah satu syarat dalam perkawinan yang wajib ada bertujuan untuk kemashalatan bagi pasangan suami istri dalam membina rumah tangga. Perjanjian perkawinan dapat dijadikan pula sebagai salah satu syarat yang wajib ada dalam perkawinan untuk memberikan perlindungan hukum secara konkret dengan bentuk perlindungan dan kepastian dalam menjamin hak dan kewajiban suami dan istri dalam rangka mewujudkan tujuan rumah tangga yaitu sakinah, mawaddah, dan rahmah sebagai tujuan syariat hukum Islam (maq\}as)id sya@ri'ah).

\section{Daftar Pustaka}

Ash-Shabuni, Muhammad Ali, Shafwatut Tafasir: Tafsir-Tafsir Pilihan (Jilid 1), Jakarta Timur: Pustaka Al-Kautsar, 2011. 
Djazuli, A., Kaidah-kaidah Fikih: Kaidah-kaidah Hukum Islam dalam Menyelesaikan Masalah-masalah yang Praktis, Jakarta: Kencana, 2007.

Doi, Rahman I., Penjelasan Lengkap Hukum-Hukum Allah (Syariah), Jakarta: PT RajaGrafindo Persada, 2002.

http://www.komnasperempuan.or.id (online Minggu 17 Mei 2015 pukul 13.34 wib)

Kitab Undang-Undang Hukum Perdata

Mardani, Hukum Islam (Pengantar Hukum Islam di Indonesia), Yogyakarta: Pustaka Pelajar, 2010.

Mertokusumo, Sudikno, Penemuan Hukum, Yogyakarta: Universitas Atma Jaya, 2010. Bambang Sunggono, Metodologi Penelitian Hukum, Jakarta: Rajawali Pers, 2012.

S, Salim H, dan Erlies Septiana Nurbani, Penerapan Teori Hukum pada Penelitian Tesis dan Disertasi, Jakarta: PT RajaGrafindo Persada, 2013.

Shihab, M. Quraish, Tafsir Al-Mishbah: Pesan, Kesan, dan Keserasian AlQur'an, Jakarta: Lentera Hati, 2002.

Sudarsono, Hukum Perkawinan Nasional, Jakarta: Rineka Cipta, 2010.

Undang-Undang Nomor 23 Tahun 2004 Tentang Penghapusan Kekerasan Dalam Rumah Tangga. 